\title{
Effect of Fenugreek Seeds in Maternal Diet on Some Features of Newborn Pups in Albino Mice
}

\author{
Karim R. Hamad* \\ Department of Biology, College of Education, Salahaddin University, Erbil, Kurdistan Region, Iraq
}

\author{
${ }^{*}$ Corresponding author: \\ Karim R. Hamad, \\ Department of Biology, \\ College of Education, \\ Salahaddin University, Erbil, \\ Kurdistan Region, Iraq. \\ E-mail: karim.hamad@ \\ su.edu.krd \\ Received: 14 October 2021 \\ Accepted: 14 December 2021 \\ Published: 30 December 2021 \\ DOI \\ 10.25156/pti.v11n2y2021.pp42-47
}

\begin{abstract}
A B S T R A C T
Introduction: Fenugreek seeds have got interest of researchers for their positive effects on laboratory animals and human being, including their effects on reproductive system. The present study aimed to investigate the effects of $5 \%$ raw fenugreek seed and its boiled aqueous extract containing diet on adult female mice, for 2 weeks before mating, to evaluate fertility, and some features of newborn pups. Materials and Methods: A total of 90 adult female mice randomly and equally were divided into three groups. Group I: Control, Group II: Female mice treated with $5 \%$ raw fenugreek seed containing diet, and Group III: Female mice treated with boiled aqueous extract of $5 \%$ fenugreek seed containing diet. The animals were treated daily for 2 weeks before mating. Some of them were mated with normal males, while the others were used for uterus study. The following parameters were evaluated: Fertility of adult female mice; body weight (BW); uterus weight; uterus sections; litter size; sex ratio; live and dead pups; and pup BW. Results: There was non-significant change in litter size and sex ratio; live and dead pups; adult female BW; and uterus weight. While wet and dry weight of pups, were significantly increased. Histological sections in uterus showed multilayering in endometrial glands of both the experimental groups. No differences were observed between fenugreek treated groups. Conclusion: Both forms of fenugreek seed (raw and aqueous extract) induced significant increase in pup weight; possibly are due to multilayering in endometrial glands of uterus.
\end{abstract}

Keywords: Fenugreek; Body weight; Litter size; Sex ratio; Endometrial glands

\section{INTRODUCTION}

Fenugreek (Trigonella foenum-graecum) can be considered as one of the medicinal plants. Fenugreek as an antidiabetic plant is wildly investigated by different ways in both diabetic animals (Puri et al., 2002, Khalil, 2004) and diabetic patients (Sharma et al., 1990, Sharma et al., 1996). Sauvaire et al., 1998, have demonstrated that the amino acid 4-hydroxy isoleucine found in fenugreek has insulinotropic and antidiabetic properties. These results were also confirmed by Broca et al., 1999. In addition, the seeds have restorative and nutritive properties (Pribac et al., 2008).

In addition to amino acids, the chemical analysis of seeds revealed its contents as moisture, fat, saponins, insoluble fiber, soluble fiber, and ash (Rao et al., 1996). Furthermore, the seeds contain flavonoid compounds (Shang et al., 1998), the alkaloids trigonelline, gentianine, and carpaine compounds (Shane-McWhorter, 2001), and large amount of metals, especially chromium (Fatima et al., 2004).

It has been shown that the aqueous extract of fenugreek seeds significantly increased body weight (BW) of normal rats (Sharaf, 1997), while non-significant changes in BW of diabetic dogs were noted after treatment with all subfractions of fenugreek seed (Ribes et al., 1987).

Sreeja et al., 2010, in their study, showed the evidence of estrogenic activities of fenugreek seeds and suggested that in vitro and in vivo studies could demonstrate its suitability as an alternative to hormonal replacement therapy. In another study, better maturation and developmental capacity rate to morula and blastocyst stage were obtained by the addition of fenugreek seed extract than addition of estradiol-17 $\beta$ (Barakat and RAl-Himaidi, 2013). Hassan et al., 2006, showed the ability of Fenugreek oil to increase the total number of cumulus-oocyte complexes and their quality in mice. In contrast, the fertility test was negative following fenugreek seeds extract treatment in rats, which explained by possible anti-estrogenic and antifertility activity of fenugreek seeds extract in female rats (Sharma and Bhinda, 2005). Moreover, the feeding diets containing $30 \%$ fenugreek seeds to male and female rabbits caused increasing in weight of newborns as a consequence of decreasing in the number of the young in the litter size as a result of nutritional competency (Kassem et al., 2006).

There are many studies carried out on the effect of fenugreek on laboratory animals and human being, 
however, still its effect on the female reproductive system and fetal features is not clear and requires further investigation.

The current research planned to study the effect of raw and boiled aqueous extract of fenugreek seeds, mixed with maternal diet, on some features of newborn pups in mice: Litter size, sex ratio, and BW; in addition to maternal BW, uterus weight, and uterus sections.

\section{MATERIALS AND METHODS}

\section{Animals}

The adult females and males of inbred mice (Mus musculus) were housed as two or three per cage in the animal house of biology department. The light/dark cycle was about I2/ $\mathrm{I} 2$ hours and room temperature about $24^{\circ} \mathrm{C}$ (Danneman et al., 2000), and the animals were provided with standard diet (Pico Lab. Rodent diet 20).

\section{Preparation of Fenugreek Seed Containing Diet}

Fenugreek ( $T$. foenum-graecum) seed powder was prepared using grinder. Part of powder added to standard diet (Pico Lab. Rodent diet 20), as a 5\% raw seed containing diet. The same amount of seed powder in preparation of $5 \%$ raw seed containing diet was used to prepare aqueous extract. According to Pandit et al., 1979, the seed powder was boiled in water, the mixture was filtered, but directly added to standard diet as boiled aqueous extract of $5 \%$ seed powder containing diet.

\section{Design of the Experiment}

Ninety adult female mice were randomly and equally divided into three groups:

Group I (control): Female mice were provided with control diet (Pico Lab. Rodent diet 20) and tap water ad libitum.

Group II (Fenugreek T1): Female mice were provided with $5 \%$ raw seed powder containing diet and tap water ad libitum.

Group III (Fenugreek T2): Female mice were provided with boiled aqueous extract of $5 \%$ seed powder containing diet and tap water ad libitum.

The treatments were continued for 2 weeks. Then, 72 females (24 in each group) were used to have mating and fertilization. Each three females were housed with one normal adult male in a cage for 10 days. After that, the females were removed and kept in individual cages until parturition.

The remainder females (six in each group) were sacrificed and dissected. The uteri were removed, weighed and recorded, and then fixed in formal saline $10 \%$.

\section{Determination of Adult Female Mice BW}

The BW of females was recorded before and after 2 weeks of treatments by digital scale.

\section{Determination of Litter Size and Sex Ratios}

At birth, the litter size of each fertilized female was recorded. According to Dodamani et al., 2017, to determine the litter size, the sum of live born and dead born pups was included in the study. Sex of newborn pups was identified by measuring the anogenital distance, which is twice as great in the male pups as it is in the females (Schneider et al., 1978). The sex ratio in each litter was determined by dividing the number of males on the total number of pups (Beery and Zucker, 2012).

\section{Determination of Pup BW}

The wet weight of newborn pups was recorded at birth by digital scale. To obtain pup dry weight, 30 pups in each group were chosen randomly, then, they were dried to a constant weight in oven kept at $60^{\circ} \mathrm{C}$, then weighed by digital scale (Girard et al., 2007).

\section{Dissection of Animals and Removing of Uterus}

Female mice were anesthetized by ketamine $(100 \mathrm{mg} / \mathrm{kg}) /$ xylazine (10 mg/kg) (Flecknell, 2009). Then, they were dissected, the uteri were removed, weighed by digital scale, and preserved in formal saline 10\%.

\section{Histological Sectioning}

Preserved uteri in formal saline exposed to serial processes and then embedded in paraffin wax. The sections were cut by rotary microtome (Drury and Wallington, 1980). They were stained with hematoxylin and eosin (Bancroft and Gamble, 2008).

\section{Statistical Analysis}

The BW, uterus weight, litter size, and sex ratio were expressed as Mean \pm standard error. Statistical analysis was conducted using GraphPad prism, version 8. The comparison of BW, uterus weight, litter size, and sex ratio was done using Tukey's multiple comparisons test. The comparison of live and dead pups was done by Chisquare test. The difference was considered significant when $P<0.05$ was considered.

\section{RESULTS}

In the present study, the adult female mice BW are shown in Table 1. The alteration in animal BW was non signification in both the experimental groups (Fenugreek T1 and Fenugreek T2) when compared to the control group.

Number of litters, liter size, and male sex ratio of pups are shown in Table 2. The alteration in litter size and male sex 
ratio in both the experimental groups was non-significant when compared to the control group.

The comparison of live and dead pups between control and fenugreek T1 [Table 3], control and fenugreek T2 [Table 4], fenugreek T1 and fenugreek T2 [Table 5] showed non-significant difference.

The BW (wet and dry weight) of pups at birth is shown in Figures 1 and 2. The pup weight, in both the experimental groups, was increased significantly as compared to control, whereas non-significant changes occurred between the experimental groups themselves.

Table 1: Effect of raw fenugreek seed and its boiled aqueous extract on adult female mice body weight

\begin{tabular}{lcc} 
Parameters & $\begin{array}{c}\text { B.wt before } \\
\text { treatment }(\mathrm{g})\end{array}$ & $\begin{array}{c}\text { B.wt after } \\
\text { treatment }(\mathrm{g})\end{array}$ \\
\hline Groups & & \\
Control $(n=30)$ & $27.12 \pm 0.352^{\mathrm{a}}$ & $27.81 \pm 0.417^{\mathrm{a}}$ \\
Fenugreek T1 $(n=30)$ & $27.4 \pm 0.347^{\mathrm{a}}$ & $28.62 \pm 0.446^{\mathrm{a}}$ \\
Fenugreek T2 $(n=30)$ & $27.69 \pm 0.338^{\mathrm{a}}$ & $28.66 \pm 0.324^{\mathrm{a}}$ \\
\hline
\end{tabular}

The same letters mean non-significant differences

Table 2: Effect of raw fenugreek seed and its boiled aqueous extract on liter size and male sex ratio

\begin{tabular}{lcccc}
\hline Parameters & $\begin{array}{c}\text { Number } \\
\text { of adult } \\
\text { females }\end{array}$ & $\begin{array}{c}\text { Number } \\
\text { of litters }\end{array}$ & Liter size & $\begin{array}{c}\text { Male sex } \\
\text { ratio }\end{array}$ \\
\hline Groups & & & & \\
$\quad$ Control & 24 & 18 & $6.5 \pm 0.414^{\mathrm{a}}$ & $0.545 \pm 0.0209^{\mathrm{a}}$ \\
Fenugreek T1 & 24 & 17 & $7.0 \pm 0.453^{\mathrm{a}}$ & $0.541 \pm 0.0104^{\mathrm{a}}$ \\
Fenugreek T2 & 24 & 20 & $6.3 \pm 0.435^{\mathrm{a}}$ & $0.546 \pm 0.0124^{\mathrm{a}}$ \\
\hline
\end{tabular}

The same letters mean non-significant differences

Table 3: Comparison of live and dead pups of control and raw fenugreek seed

\begin{tabular}{lccc}
\hline Parameters & Live pups & Dead pups & Total \\
\hline Groups & & & \\
Control & $99(82.5 \%)$ & $21(17.5 \%)$ & 120 \\
Fenugreek T1 & $106(86.18 \%)$ & $17(13.82 \%)$ & 123 \\
\hline
\end{tabular}

Chi-square $\left(\chi^{2}\right)$ value $=0.482 P=($ N.S $)$

Table 4: Comparison of live and dead pups of control and boiled aqueous extract

\begin{tabular}{lccc}
\hline Parameters & Live pups & Dead pups & Total \\
\hline Groups & & & \\
Control & $99(82.5 \%)$ & $21(17.5 \%)$ & 120 \\
Fenugreek T2 & $110(87.3 \%)$ & $16(12.7 \%)$ & 126 \\
\hline
\end{tabular}

Chi-square $\left(\chi^{2}\right)$ value $=0.372 P=(\mathrm{N} . \mathrm{S})$

Table 5: Comparison of live and dead pups of raw fenugreek seed and its boiled aqueous extract

\begin{tabular}{lccc}
\hline Parameters & Live pups & Dead pups & Total \\
\hline Groups & & & \\
Fenugreek T1 & $106(86.18 \%)$ & $17(13.82 \%)$ & 123 \\
Fenugreek T2 & $110(87.3 \%)$ & $16(12.7 \%)$ & 126 \\
\hline
\end{tabular}

Chi-square $\left(\chi^{2}\right)$ value $=0.852 P=($ N.S $)$
The uterus absolute and relative weight in both the experimental groups were changed non-significantly as compared to control [Table 6].

The histological sections in the uterus of control, fenugreek T1, and fenugreek T2 are shown in Figures 3-5, respectively. The histological section in uterus of fenugreek T1 shows multilayering glands in endometrium. The same changes were observed in uterus section of fenugreek T2, while uterus section of control showed endometrial glands in proliferative activity lined by a single layer.

\section{DISCUSSION}

In the present study, treatment of adult female mice with $5 \%$ raw fenugreek seed powder containing diet and boiled aqueous extract of 5\% fenugreek seed powder containing diet for 2 weeks before mating with adult males caused non-significant change in BW, which is not consistent with that of Sharaf, 1997, and Geetha et al., 2011. The first one reported that the aqueous extract of fenugreek seeds significantly increased BW of normal rats, while the second one showed reduction of the total body and adipose tissue weight in a dose-dependent manner. This controversy most probably related to dose and exposure period.

Table 6: Effect of raw fenugreek seed and its boiled aqueous extract on uterus weight of adult females

\begin{tabular}{lcc}
\hline Parameters & Absolute wt. (mg) & Relative wt. (mg) \\
\hline Groups & & \\
Control $(n=6)$ & $109.5 \pm 12.4^{\mathrm{a}}$ & $405.8 \pm 43.7^{\mathrm{a}}$ \\
Fenugreek T1 $(n=6)$ & $104.7 \pm 18.87^{\mathrm{a}}$ & $415.3 \pm 63.6^{\mathrm{a}}$ \\
Fenugreek T2 $(n=6)$ & $98.17 \pm 10.26^{\mathrm{a}}$ & $327.8 \pm 28.1^{\mathrm{a}}$ \\
\hline
\end{tabular}

The same letters mean non-significant differences

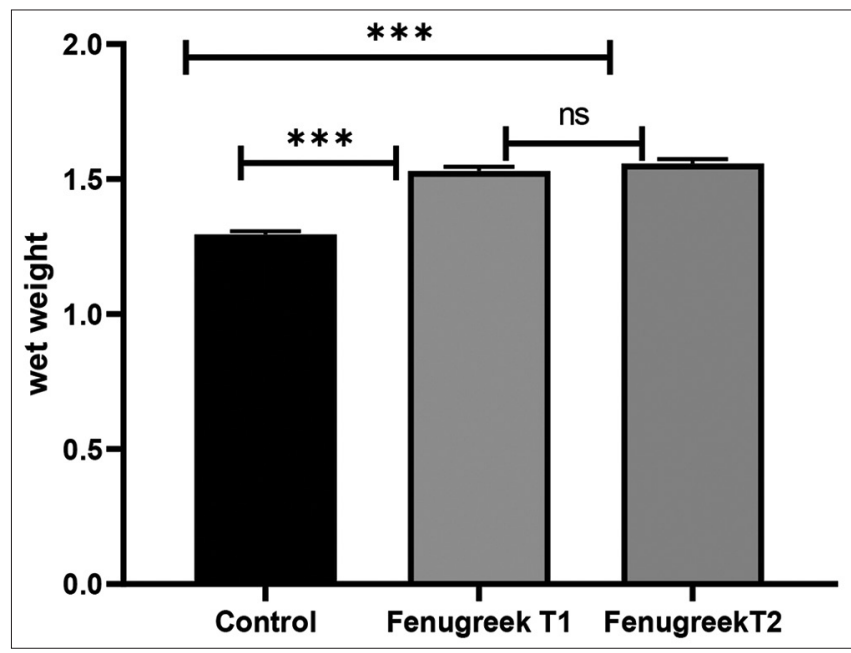

Figure 1: Effect of raw fenugreek seed and its boiled aqueous extract on pup wet weight. Control $=1.295 \pm 0.0118 \mathrm{~g}(n=120)$, fenugreek T1 $=1.530 \pm 0.0164 \mathrm{~g}(n=123)$, and fenugreek T2 = 1.557 $\pm 0.0174 \mathrm{~g}(n=126)$. N.S: Non-significant differences. ${ }^{* * *}=P<0.001$ 


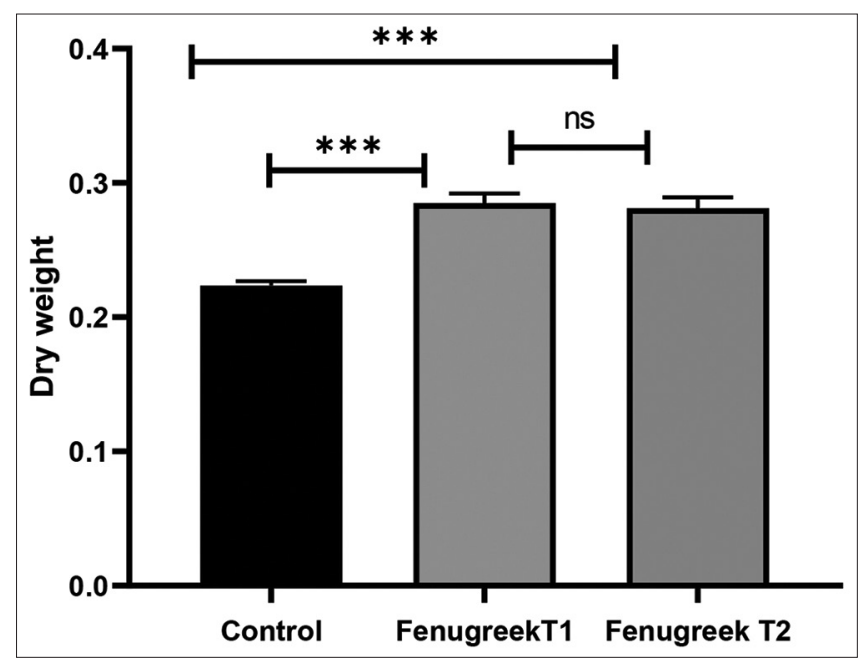

Figure 2: Effect of raw fenugreek seed and its boiled aqueous extract on pup dry weight. Control $=0.223 \pm 0.0033 \mathrm{~g}(n=30)$, fenugreek T1 $=0.285 \pm 0.0070 \mathrm{~g}(n=30)$, and fenugreek T2 $=0.281$ $\pm 0.0080 \mathrm{~g}(n=30)$. N.S: Non-significant differences. ${ }^{* * *}=P<0.001$

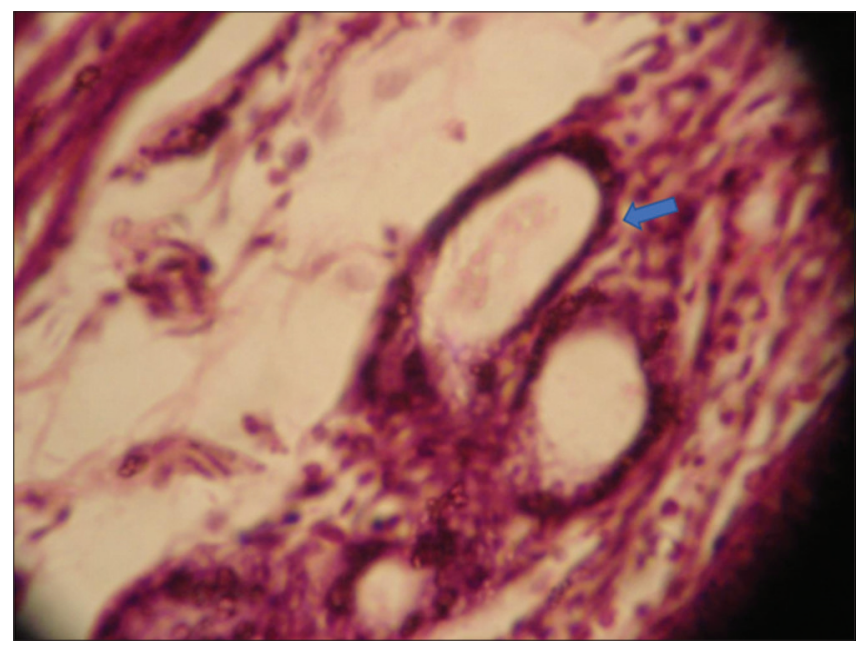

Figure 3: Section from endometrium of uterus of control mouse, showing endometrial glands lined by a single layer (arrow) (Stain: hematoxylin and eosin. 400x)

The significant increase in pup weight in both the experimental groups in agreement with the results was gained by Seleem, 2008, and Deshpande et al., 2016. The first one showed increasing in both pup weight and litter size with a dose of $0.3 \%$ fenugreek containing diet in rabbit. Indeed, the study showed significant increase in litter size parallel with significantly increased pup weight. Deshpande et al., 2016, who demonstrated the mean fetal weights of male and female fetuses from low-molecular-weight galactomannans-based standardized fenugreek seed extract (LMWGAL-TF) (500 and $1000 \mathrm{mg} / \mathrm{kg}$ ) treated group were significantly higher as compared to the control group. However, they considered this change in fetal weight as incidental and not considered to be biologically significant.

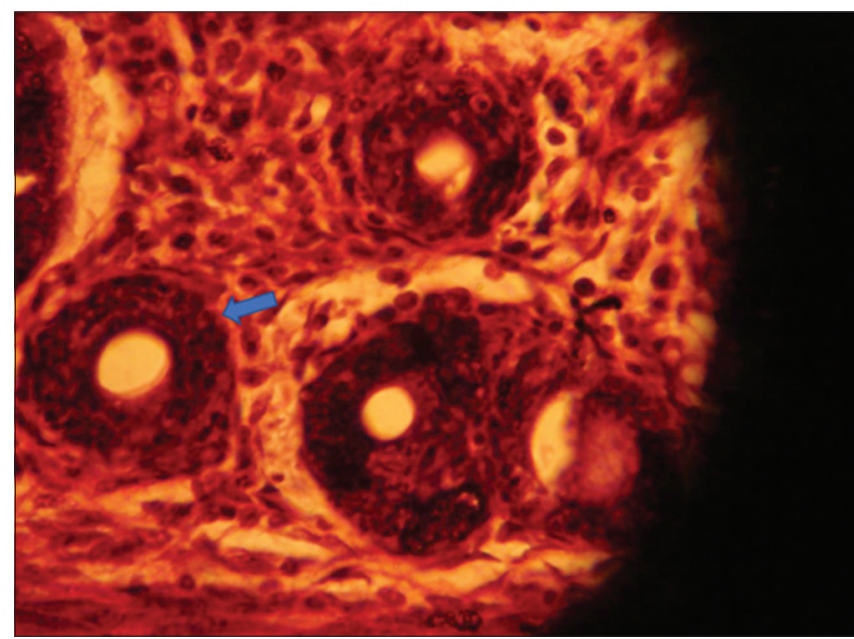

Figure 4: Section from endometrium of uterus of mouse treated with raw fenugrek seed showing multilayering glands (arrow) (Stain: hematoxylin and eosin. 400x)

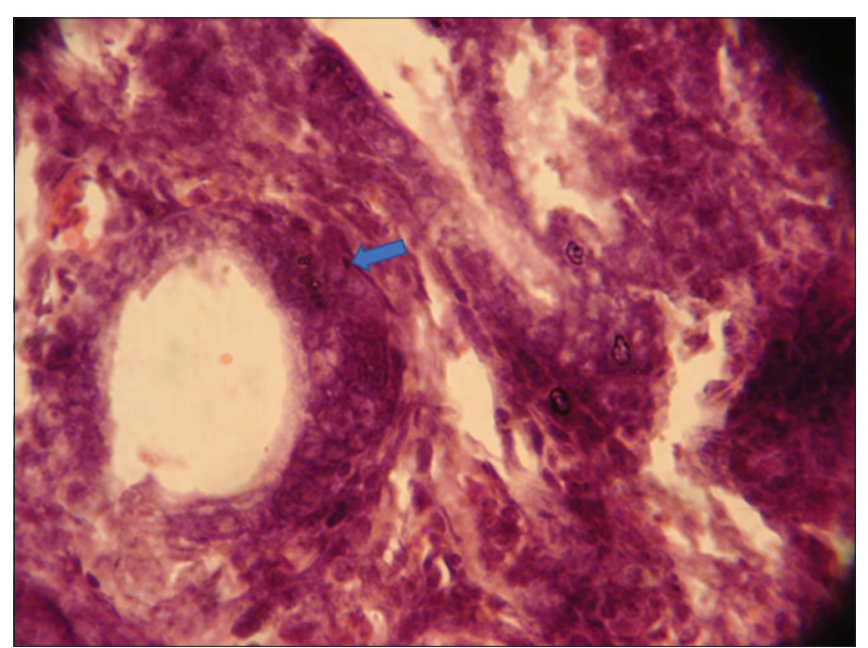

Figure 5: Section from endometrium of uterus of mouse treated with boiled aqueous extract of fenugreek seed showing multilayering glands (arrow) (Stain: hematoxylin and eosin. 400x)

Furthermore, Kassem et al., 2006, investigated 30\% fenugreek seeds containing diet on female rabbits for 3 months, they were reported increasing in weight of newborns, and explained such increasing in BW as a consequence of decreasing in the number of the young in the litter size as a result of nutritional competency. In the present study, since we used a lower dose of fenugreek before mating and we got non-significant change in both litter size and sex ratio of both groups, so the above explanation may be not applicable. This difference most probably is dose dependent, and due to exposure period and time of fenugreek administration. In our study, both pups' wet and dry weight, in both the experimental groups, were increased significantly compared to control. In literature, we could not find any data about the effect of fenugreek on pup dry weight. Such change in pup dry weight proves the fact that the increase in wet weight is 
possibly due to tissue mass growth and may be not related to increasing in hydration-like edematous conditions.

The litter size and sex ratio in both the experimental groups were nonsignificant when compared to the control group. From literature, it is clear that the antifertility effect of FGS is dose and sex dependent. Hence, the present study is in agreement with Deshpande et al., 2016, and close to that of Seleem, 2008, and Hamad et al., 2010. The first one reported that LMWGAL-TF treated dams did not show adverse effect in terms of a number of fetuses and sex ratio of fetuses, while Seleem, 2008, showed that rabbit does fed diets supplemented with $0.3 \%$ fenugreek and mated naturally using bucks fed the same supplemented diets recorded significantly higher values of litter size. Hamad et al., 2010, reported that treatment of male rats with $5 \%$ fenugreek seed powder and its aqueous extract containing diet for 4 weeks increased the male sex ratio in the rat, while the litter size is increased only in treatment with aqueous extract. It means low dose in female may have advantageousness effects on fertility at the time when it possibly increases the fertility in male.

Regarding the fertility, our results have clear disagreement with the work of authors, who used higher doses of FGSE. Sharma and Bhinda, 2005, used steroidal extract of fenugreek seeds $100 \mathrm{mg}$ /day for 15 days in female rats. As a result, the fertility test was negative and suggested that it exerts anti-estrogenic and antifertility activity in female rats. Kassem et al., 2006, investigated 30\% fenugreek seed containing diet in male and female rabbits, who clearly demonstrated antifertility effect of fenugreek seeds in female rabbits and more of a toxicity effect in the male rabbits. In addition, Anjula and Sharma, 2018, revealed that steroidal fraction $50 \mathrm{mg}$ of fenugreek for 12 days inhibits fertility of up to $50 \%$ in female rats. However, higher dose $100 \mathrm{mg}$ of seed extract showed 100\% negative fertility.

In the view of the present study and observations above, the liter size and sex ratio are dependent on dose, period exposure and time of fenugreek administration, and the sex of investigated animals.

In both treated groups of the present study, fenugreekinduced non-significant change in live and dead pups. Whereas (Khalki et al., 2010) recorded induction of foetal death rate in mice treated with fenugreek seed aqueous extract. This difference with the present study most probably is dependent on dose, period exposure, and time of fenugreek administration

In the present study, the uterus absolute and relative weight both treated groups were changed non-significantly as compared to control. This result is the same of Hilles et al., 2016, who showed nonsignificant change in uterine weight of treated rats with fenugreek seeds aqueous extract $750 \mathrm{mg} / \mathrm{kg}$ for 15 days. Even increasing in both dose and duration by Deshpande et al., 2016, to $1000 \mathrm{mg} / \mathrm{kg}$ lowmolecular-weight galactomannans-based standardized fenugreek seed extract and for 90 days did not cause significant change in uterine weight in rats.

In the present study, the histological sections in the uterus of fenugreek T1 and T2 showed multilayering glands in endometrium, while uterus section of control showed endometrial glands in proliferative activity lined by a single layer. It is proven that endometrial glands aid in providing nutrition to the implanted ovum (JE, 2011). Therefore, such multilayering glands in endometrium of uteri possibly positively affect the increasing in pup weight.

\section{CONCLUSION}

The study proved significant increasing in pup wet and dry weight in both the experimental groups (raw and boiled aqueous extract of fenugreek seeds). Such change in dry weight proves that the increase in wet weight is possibly due to tissue mass growth, most probably due to multilayering in endometrial glands of uterus, which aid in providing nutrition to the implanted ovum.

\section{REFERENCES}

Anjula, B. and J. Sharma, J. 2018. Postcoital antifertility activity of steroidal fraction of fenugreek seeds in rats. GJAR. 5: 70-75.

Bancroft, J. D. and M. Gamble. 2008. Theory and Practice of Histological Techniques. Elsevier Health Sciences, Amsterdam, Netherlands.

Barakat, I. A. and A. Ral-Himaidi. 2013. Effects of fenugreek seed extract on in vitro maturation and subsequent development of sheep oocytes. Pak. J. Zool. 45: 1679-1686.

Beery, A. K. and I. Zucker. 2012. Sex ratio adjustment by sex-specific maternal cannibalism in hamsters. Physiol. Behav. 107: 271-276.

Broca, C., R. Gross, P. Petit, Y. Sauvaire, M. Manteghetti, M. Tournier, P. Masiello, R. Gomis, and G. Ribes. 1999. 4-Hydroxyisoleucine: Experimental evidence of its insulinotropic and antidiabetic properties. Am. J. Physiol. Endocrinol. Metab. 277: E617-E623.

Danneman, P. J., M. A. Suckow and C. Brayton. 2000. The Laboratory Mouse. CRC Press, Boca Raton, Florida, United States.

Deshpande, P., V. Mohan, P. Thakurdesai, M. Pore and S. Gumaste. 2016. Prenatal developmental toxicity evaluation of low molecular weight galactomannans based standardized fenugreek seed extract during organogenesis period of pregnancy in rats. Int. J. Pharm. Pharm. Sci. 8: 248-253.

Dodamani, M. S., A. Krishnaswamy, S. S. Honnappagol, S. YATHIRAJ, M. Narayanswamy, G. Sudha and V. Chandrashekarmurthy. 2017. Birth weight, litter size, sex ratio and neonatal mortality in purebred Mudhol hounds. Int. J. Sci. Environ. Technol. 6: 2307-2317.

Drury, R. and E. Wallington. 1980. Preparation and fixation of tissues. Carletons Histol. Tech. 5: 41-54. 
Fatima, N., I. U. Siddiqui, F. Perveen and Z. Maqsood. 2004. Among few commonly used anti-diabetic herbs: Fenugreek is the best. Pak. J. Biol. Sci. 7: 966-970.

Flecknell, P. A. 2009. Laboratory Animal Anaesthesia. Univerza v Ljubljani, Veterinarska Fakulteta.

Geetha, M., K. Suneel, A. Krupanidhi, K. Muralikrishna, A. Avin and P. Prashanth. 2011. Effect of fenugreek on total body and organ weights: A study on mice. Pharmacologyonline. 3: 747-752.

Girard, I., E. L. Rezende and T. Jr. Garland. 2007. Leptin levels and body composition of mice selectively bred for high voluntary locomotor activity. Physiol. Biochem. Zool. 80: 568-579.

Hamad, K. R., F. T. Juma and S. A. Ali. 2010. Effects of fenugreek (Trigonella foenum-graecum) seeds on reproductive efficiency in normal and alloxan induced diabetic male rats. J. Duhok Univ. 13: $118-129$.

Hassan, A. M., W. K. Khalil and K. A. Ahmed. 2006. Genetic and histopathology studies on mice: Effect of fenugreek oil on the efficiency of ovarian and liver tissues. Afr. J. Biotechnol. 5: 477483.

Hilles, A. R., A. K. Allow and S. Mahmood. 2016. Evaluation and comparison of the antifertility potential activity and adverse effects of Trigonella foenum-graecum seeds and combined oral contraceptive pills in female rats. Int. J. Reprod. Contracept. Obstet. Gynecol. 5: 680-688.

Je, H. 2011. Guyton and Hall Textbook of Medical Physiology. Vol. 107. Saunders, Elsevier, Philadelphia, PA, p1146.

Kassem, A., A. Al-Aghbari, A. H. Molham and M. Al-Mamary. 2006. Evaluation of the potential antifertility effect of fenugreek seeds in male and female rabbits. Contraception. 73: 301-306.

Khalil, E. A. 2004. Biochemical and histopathological studies on the influence of aqueous extract of fenugreek seed (Trigonella foenum graecum) on alloxan diabetic male rats. Egypt. J. Hosp. Med. 15: 83-94.

Khalki, L., S. B. M'Hamed, M. Bennis, A. Chait and Sokar, Z. 2010. Evaluation of the developmental toxicity of the aqueous extract from Trigonella foenum-graecum (L.) in mice. J. Ethnopharmacol. 131: 321-325.

Pandit, N., J. Singh and D. Bhattacharjee. 1979. Impact of feeding chakwar (Cassia tora) seed on the growth of broilers. Indian J. Poult. Sci. 49: 623-630.

Pribac, G. C., A. Ardelean, V. Turcuş, C. C. Toma, C. Cotoraci, L. Moş and C. Crăciun. 2008. Data regarding the morphologic and chemical characterization of Trigonella foenum-graecum seeds. In: Studia Universitatis Vasile Goldis Seria Stiintele Vietii (Life
Sciences Series), p18.

Puri, D., K. Prabhu and P. Murthy. 2002. Mechanism of action of a hypoglycemic principle isolated from fenugreek seeds. Indian J. Physiol. Pharmacol. 46: 457-462.

Rao, P. U., B. Sesikeran, P. S. Rao, A. N. Naidu, V. V. Rao and E. Ramachandran. 1996. Short term nutritional and safety evaluation of fenugreek. Nutr. Res. 16: 1495-1505.

Ribes, G., C. Da Costa, M. Loubatières-Mariani, Y. Sauvaire and J. Baccou. 1987. Hypocholesterolaemic and hypotriglyceridaemic effects of subfractions from fenugreek seeds in alloxan diabetic dogs. Phytother. Res. 1: 38-43.

Sauvaire, Y., P. Petit, C. Broca, M. Manteghetti, Y. Baissac, J. Fernandez-Alvarez, R. Gross, M. Roye, A. Leconte and R. Gomis. 1998. 4-Hydroxyisoleucine: A novel amino acid potentiator of insulin secretion. Diabetes. 47: 206-210.

Schneider, J. E., C. J. Wysocki, J. Nyby and G. Whitney. 1978. Determining the sex of neonatal mice (Mus musculus). Behav. Res. Methods Instrum. 10: 105-105.

Seleem, T. 2008. Rabbit productivity and reproductivity as affected by fenugreek in diets. In: The $1^{\text {st }}$ Egyptin Conference on Rabbits Sciences, p142-153.

Shane-Mcwhorter, L. 2001. Biological complementary therapies: A focus on botanical products in diabetes. Diabetes Spectr. 14: 199-208.

Shang, M., S. Cai, J. Han, J. Li, Y. Zhao, J. Zheng, T. Namba, S., Kadota, Y. Tezuka and W. Fan. 1998. Studies on flavonoids from Fenugreek (Trigonella foenum graecum L.). Zhongguo Zhong. Yao Za Zhi. 23: 614-616, 639.

Sharaf, O. 1997. Pharmacological and toxicological effects of fenugreek and anise water extracts in rats. J. Egypt. German Soc. Zool. 24: 257-272.

Sharma, J. and A. Bhinda. 2005. Antifertility activity of steroidal extract of Trigonella foenum-graecum (seeds) in female rats. Asian J. Exp. Sci. 19: 115-120.

Sharma, R., A. Sarkar, D. Hazara, B. Mishra, J. Singh, S, Sharma, B. Maheshwari and P. Maheshwari. 1996. Use of fenuqreek seed powder in the management of non-insulin dependent diabetes mellitus. Nutr. Res. 16: 1331-1339.

Sharma, R., T. Raghuram and N. S. Rao. 1990. Effect of fenugreek seeds on blood glucose and serum lipids in Type I diabetes. Eur. J. Clin. Nutr. 44: 301-306.

Sreeja, S., V. Anju and S. Sreeja. 2010. In vitro estrogenic activities of fenugreek Trigonella foenum graecum seeds. Indian J. Med. Res. 131: 814. 